\title{
Scope of distraction osteogenesis in dentistry - a mini review
}

\author{
Ajay Mahajan ${ }^{*}$, Divya Kashyap ${ }^{1}$, Baljeet Singh¹, Amit Kumar and Poonam² \\ *Correspondence: julius05@rediffmail.com \\ ${ }^{1}$ Himachal Pradesh Government Dental College and Hospital (H.P.G.D.C.) Shimla-H.P., India. \\ ${ }^{2}$ Indian Association of Public Health Dentistry, India.
}

\begin{abstract}
Distraction osteogenesis has emerged as an effective treatment modality for the correction of bone anomalies and abnormalities which are either pathological or developmental in origin. Earlier it was predominantly used in orthopaedics for the correction of axial skeleton. Its use in the field of dentistry began in the late twentieth century. Successful results from the initial clinical trials prompted more and more researchers to explore this field. Its use in dentistry involves the correction of craniofacial anomalies, alveolar ridge for the prosthetic rehabilitation and recently for the regeneration of lost periodontium.
\end{abstract}

Keywords: Distraction osteogenesis, dentistry, review, regeneration

\section{Introduction}

Bone is a dense, semi rigid, porous, calcified connective tissue composed of a dense organic matrix and an inorganic, mineral component. It is a metabolically active organ that undergoes continuous remodelling resorption and formation. The process is regulated by both local and systemic factors. Normally there is a balance between bone formation and bone breakdown. If bone breakdown comes to predominate, as in pathological conditions, bone substance and structure are lost and results in bone resorption [1].

Bone loss is a commonly encountered condition in the dental patients, which may result from the atrophy of edentulous segment after tooth extraction, trauma, tumour resection but most commonly is a result of periodontitis. Various techniques have been developed for treating osseous defects eg., bone graft, guided bone regeneration, tissue engineering. Distraction osteogenesis is an emerging technique in bone regeneration, showing promising results with some unique advantages [2]. Distraction osteogenesis is defined as the creation of neoformed bone and adjacent soft tissue after the gradual and controlled displacement of a bone fragment obtained by surgical osteotomy. Some tissues besides bone have been observed to form under tension stress, including mucosa, skin, muscle, tendon, cartilage, blood vessels, and peripheral nerves $[3,4]$.

It has been recently introduced in the field of dentistry for the treatment of bone defects. As a result of successful clinical trials, researchers now believe that distraction osteogenesis will start a new era of treatment, superseding other treatment modalities of bone reconstruction. Thus the purpose of this review is to discuss the various aspects of distraction osteogenesis and its scope in the field of dentistry.

\section{Historical background}

Codvilla, in, 1905 was the first to perform extremity lengthening by the application of external traction [5]. The credit of popularising the technique world-wide goes to Gavril llizarov, a Russian orthopaedic surgeon. In the late 1980s he published in America for the first time his research and clinical results on the bone distraction, causing a wave of developments in the bone distraction technique worldwide [6]. Synder et al., 1973 were the first to apply the llizarov's principles of distraction osteogenesis for the regeneration of the osteotomized mandible [7]. Micheal \& Miotti, 1997 demonstrated the feasibility of intraoral mandibular lengthening [8]. McCarthy et al., 1989 were the first to clinically apply extraoral distraction osteogenesis on four boys with congenital anomalies such as hemifacial microsomia and Nager's syndrome. This report ushered in the modern era of clinical craniofacial distraction [9].

\section{Biological principles}

Based on clinical experience, llizarov discovered two biological principles [9,10], "Ilizarov effects":

1. Tension-stress effect on the growth and genesis of tissues. This suggested that when two bone plates are separated, there is pressure acting on one side and tension on the other side of the device in situ. Thus, due to these physiologic changes, the osteoblasts are stimulated to grow, thus helping in new bone formation.

2. The influence of blood supply and loading on the shape of bones and joints.

Distraction osteogenesis consists of five sequential periods: Osteotomy

Latency

(ㄷ) 2013 Mahajan et al; licensee Herbert Publications Ltd. This is an Open Access article distributed under the terms of Creative Commons Attribution License (http://creativecommons.org/licenses/by/3.0). This permits unrestricted use, distribution, and reproduction in any medium, provided the original work is properly cited. 


\section{Distraction}

Consolidation

Remodeling

\section{Osteotomy}

Osteotomy is the surgical separation of bone into two segments. Osteotomy causes loss of mechanical integrity, triggering fracture healing, which involves recruitment of osteoprogenitor cells, followed by cellular modulation (osteoinduction) and establishment of environment template (osteoconduction).

\section{Latency}

It is the period from bone division to the onset of traction and represents the time required for reparative callous formation between the osteotomised bone segments. Initially, there is formation of a hematoma, which is converted into a clot. This is followed by vasoformative elements leading to capillary proliferation. Callus formation is a response determined by the osteoprogenitor cells originating in the periosteum and endosteum.

\section{Distraction}

It is the time when a traction force is applied to bone segments and new bone or distraction regenerate is formed within the intersegmentary gap. The growth stimulating effect of tension activates the biologic elements of intersegmentary connective tissue.

Two major parameters of critical importance during this period are:

Distraction Rate

Distraction rhythm

- Distraction rate is defined as the numbers of millimetres per day at which the bone surfaces are stretched. An average distraction rate of 1-1.5 $\mathrm{mm}$ per day proves the best clinical results [11].

- Distraction rhythm is the number of distractions per day, usually in equally divided increments to total the rate. Two activations per day are done, and the patient is usually admitted to the clinic and kept under observance. The pitch of the device is set in such a way that $1 \mathrm{~mm}$ of distraction is brought about after four turns of the screw (pitch of screw maintained at $0.25 \mathrm{~mm}$ or $0.5 \mathrm{~mm}$ ).

\section{Consolidation}

It begins when the traction force is discontinued and the desired amount of bone length has been achieved. This period allows mineralisation and the corticalization of the newly formed bone tissue prior to the distraction device removal.

\section{Remodelling}

It is the time after the removal of the distraction device.
Although this period usually continues for approximately 1 year after the completion of distraction, remodelling of the newly formed bone begins at the completion of distraction and continues throughout the consolidation period.

\section{Histological aspect of distraction osteogenesis}

Distraction osteogenesis shares many features of embryonic growth, as well as normal fracture gap healing [13].

\section{The effect of osteodistraction on bone Latency phase}

The latency phase allows for the initial trauma response to take place. Following osteotomy a hematoma is formed that encircles the osteotomised bone segments. Granulation tissue that consist of soft-connective tissue cells, neutrophils and invading capillaries replace the hematoma after several days and this tissue subsequently transforms into soft callous.

\section{Distraction phase}

During the distraction phase, tensile forces are applied to the callus with a specific rate and rhythm. As the callus is stretched, a central fibrous zone, called the fibrous interzone forms. It is rich in chondrocyte-like cells, fibroblasts, and oval cells, which are morphologically intermediate between fibroblasts and chondrocytes. The differentiating osteoblasts at the fibrous interzone deposit osteoid along collagen bundles. They subsequently undergo mineral crystallization parallel to the collagen bundles, forming a zone called the 'zone of microcolumn formation'. In between the fibrous interzone and microcolumn formation, a zone of highly proliferating cells, called the 'primary matrix' or 'mineralization front', is observed [12].

\section{Consolidation phase}

Once the desired bone length is achieved, distraction ceases, marking the beginning of the consolidation phase, where bone and extensive amounts of osteoid undergo mineralization and eventual remodelling.

\section{The effect of osteodistraction on gingiva}

Distraction forces applied to bone also create tension in the surrounding tissues, initiating a sequence of adaptive changes termed distraction histogenesis. Under the influence of tensional stress produced by gradual distraction, active histogenesis has been reported in various soft tissues surrounding the distracted bony segments [14].

Therefore the primary mechanism by which gingiva undergoes adaptation during osteodistraction is by neohistogenesis.

The role of growth factors and cytokines in distraction osteogenesis

Recent molecular investigations have indicated that the 


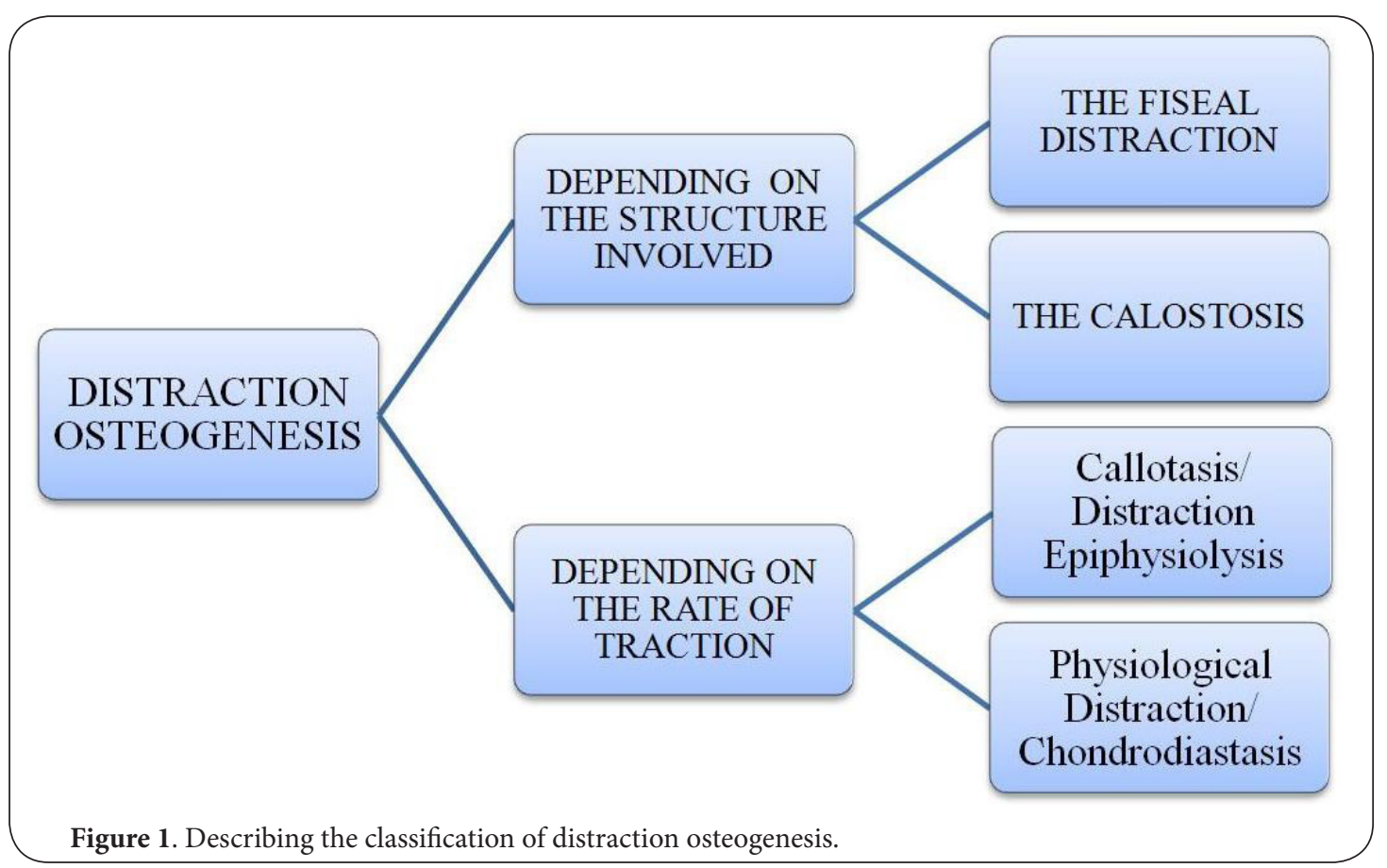

molecular signalling cascade plays an important role in the relationship between induced strain and bone regeneration.

Bone Morphogenic proteins (BMPs) play

An important role in the signalling pathways that link the mechanical forces created by distraction to biological responses [15]. They accelerate the differentiation of the precursor cells into chondrogenic osteogenic cells.

\section{Transforming Growth Factor Beta (TGF- $\beta$ )}

Suppresses osteoblast maturation by delaying differentiation of osteoblasts during the mineralization stage of distraction osteogenesis [16].

\section{Interleukin-1, Interleukin-6 (IL-1, IL-6)}

Have been hypothesized to contribute to intramembranous ossification, by enhancing the differentiation of cells committed to the osteoblastic linage.

Insulin-Like Growth Factors (IGF-1) And Basic Fibroblast Growth Factor (bFGF)

Account for osteoblast proliferation and formation from precursor mesenchymal cells in the distracted area.

Vascular Endothelial Growth Factor (VEGF)

Induces neoangiogenesis during distraction osteogenesis.

Enhancement of bone formation during distraction osteogenesis

Long treatment time is a major disadvantage of distraction osteogenesis. Various treatment modalities have been used to promote bone growth during distraction osteogenesis.
These modalities involve:

\section{Mechanical modulation}

Researchers found that by increasing the frequency of distraction and decreasing the amount of lengthening at each interval, bone formation can be improved [17].

\section{Low-intensity Pulsed Ultrasound}

Studies have shown that use of Low intensity Pulsed Ultrasound accelerated new bone formation during the distraction period [18].

\section{Electrical stimulation}

Studies have shown that electrical stimulation during gradual distraction promotes new bone formation [19].

\section{Growth factors and stem cells}

Use BMPs [20], COMP-Ang1, an angiogenic factor [21], recombinant human bone morphogenetic protein-2 and recombinant human osteoprotegerin [22], Platelet rich plasma [23] injections of osteogenic bone marrow stromal cell [24], have shown to enhance bone formation in distraction osteogenesis.

\section{Hyperbaric oxygen}

Researchers have found that hyperbaric oxygen treatment was effective in stimulating vascularization and bone formation during distraction osteogenesis [25].

\section{Intermittent Parathyroid Hormone}

Intermittent PTH(1-34) treatment enhances new bone formation during distraction osteogenesis [26] (Figure 1). 


\section{Scope of distraction osteogenesis in dentistry}

Distraction osteogenesis originally developed for the orthopaedic field and later applied to the maxillofacial region for the correction of severe craniofacial malformations has been more recently introduced to correct vertical defects of the alveolar ridge to improve bone volume for dental implant placement.

\section{Correction of craniofacial anomalies}

Maxillomandibular hypoplasia, facial asymmetry, and congenital micrognathia are relatively common abnormalities of the craniofacial complex. Traditionally, these skeletal deformities have been addressed in nongrowing patients via osteotomies followed by acute orthopaedic movements and skeletal fixation, with or without interpositional bone grafts. Despite the fact that conventional orthognathic surgery and craniofacial reconstruction have experienced widespread success, several limitations are associated with these treatment modalities. Distraction osteogenesis depicts the shift from the era of transplantation surgery (reconstruction/replacement) to the era of inductive surgery. Distraction osteogenesis not only results in the formation of bone but also create tension in the surrounding soft tissues, initiating a sequence of adaptive changes termed distraction histogenesis [27].

\section{Craniofacial devices}

\section{Mandibular distractors}

McCarthy extraoral osteodistractor

In 1989 McCarthy et al., performed first extraoral mandibular distraction in children with craniofacial anomalies. The technique involved osteotomy by a series of drill holes which wwere subsequently joined. Hoffmans Mini Lengthener was then attached to the bone segments and distraction was performed [9].

\section{Molina and Ortiz-Monasterio mandibular distractor} Molina and Ortiz-Monasterio gave semirigid extraoral fixation system. The technique involved cricotomy of the bone segment leaving the medial bone intact, followed by fixations by only one pin inserted and secured on both bone segments. They were the first to perform the bidirectional osteodistraction in mandible by generating two distraction sites followed by lengthening of the both parts of the mandible together [28].

Multidirectional extraoral distraction appliances resulted from the combination of bidirectional distraction appliance with gradual angular adjustment. This allowed correction of severe mandibular deformities in three dimensional space.

ACE/Normed device permitted double level lengthening but multidimensional correction was difficult to achieve. Multiguide Mandibular distractor provided three dimensional rotation of the bone segment but did not allowed the bidirectional mandibular correction. These limitations prompted the development of intraoral device.
Guerrero intraoral mandibular distractor

Guerrero et al., developed different intraoral distraction device tooth-borne, bone-borne, and hybrid intraoral devices for mandibular lengthening and widening. These devices can be modified by attaching either to orthodontic band or to pair of bendable metallic arms. Intraoral distraction devices had a major advantage of being aesthetically more pleasing as they were not conspicuous and were not associated with facial scar [10].

Razdolsky tooth-borne and hybrid devices (ROD) Razdolsky et al., developed a series of tooth-borne and hybrid devices (ROD) in which the distraction mechanism can be attached to stainless steel crowns or miniplates [30].

Mandibular distraction osteogenesis has emerged as a successful treatment modality for treating the mandibular defects resulting from the congenital diseases such as Pierre Robin syndrome [31,32] \& Unilateral craniofacial defects; bone defects resulting from trauma or oncologic bone resection [33]; patients of TMJ ankylosis and for the management of pediatric airway $[34,35]$.

\section{Maxillary and midfacial distractors}

In 1993 Rachmiel et al., were the first to demonstrate the possibility of maxillary distraction [36].

\section{Rigid external distraction (RED)}

Polly et al., 1995, performed the first midface distraction in humans. They used an externally fixed cranial halo to distract the midface. Advantages of the technique were the ease of application, activation and removal of distractor without the need of second surgical procedure [37].

\section{Modular Internal Distraction (MID) System}

Cohen, 1995 developed the MID system which is attached to cranium or zygoma and to maxillary skeleton. Activation rod is externalised through a subcutaneous tunnel. Advantage of this technique is the controlled complete advancement of the entire midface [28].

\section{Nakajima's angle-variable internal distraction} (NAVID) system

To overcome the difficulties associated with the distraction devices such as large size and the need for a facial mask causing much psychological stress to the patient treated with external distractors and internal distractors being difficult to control and remove Nakajima et al., designed an internal distraction device-Nakajima's angle-variable internal distraction (NAVID) system-and assessed its clinical applicability. They found the NAVID system to be a safe, effective and reliable for all types of Le Fort distraction osteogenesis [38].

\section{Combined Mandible and LeFort I distraction}

Ortiz-Monasterio and Molina, 1999 introduced a technique 
for simultaneous correction of maxillary-mandibular deficiencies. This technique involved Le Fort cricotomy along with mandibular osteotomy and placement of distraction device [39].

Maxillary distraction osteogenesis has shown successful results in the treating the patients suffering from Crouzon syndrome $[40,41,42]$, Sotos Syndrome [43], traumatic or oncologic surgical maxillofacial resections $[44,45]$, and severe maxillary hypoplasia in cleft lip and palate $[46,47]$. Studies have shown distraction osteogenesis to be a better option than orthognathic surgery for the treatment of patients requiring moderate to large advancements with significant structural deficiencies of the maxilla [48].

\section{Three dimensional distraction osteogenesis}

Some researchers performed the three dimensional distraction osteogenesis and found that it allowed to simultaneously and selectively widen, lengthen and vertically reposition the maxilla, producing acceptable post-treatment skeletal and dental relationships, without healing problems observed clinically [49].

Sugawara et al., performed multidirectional cranial distraction osteogenesis for the treatment of craniosynostosis [50].

\section{Zygomatic distraction}

Zygomatic deficiencies are frequently seen in the children with disorders such as severe orbitofacial clefts and the Treacher Collins Syndrome. Phillips et al., reported the first laboratory zygomatic distraction using an external distractor on the canine model [51]. Capote Moreno et al., performed zygomatic distraction osteogenesis for correction of midfacial support after hemimaxillectomy [52]. Zygomatic distraction was found to be an excellent treatment regime in patients with severe maxillary defects with insufficient bone and in whom other reconstructive methods have failed.

Reconstruction of the temporoporomandibular joint Studies on the effect of mandibular distraction on the temporomandibular joint have shown that the condyles assume a more normal anatomic size, shape and position after distraction. McCormin et al., performed a two-part study on the effects of distraction on the temporomandibular joint and found that the process of distraction was beneficial to the structure and position of the temporomandibular joint $[53,54]$.

Schwartz and Relle evaluated the use of distraction osteo-genesis in the reconstruction of ramus condylar unit in the temporomandibular joint. They found that distraction resulted in the development of solid regenerate bone and an effective new articulation [55].

Yu et al., utilised gap arthroplasty and distraction osteogenesis simultaneously in the treatment of unilateral ankylosis of the temporomandibular joint in patients with micrognathia [56].

\section{Transport distraction osteogenesis}

Transport distraction osteogenesis can be defined as the creation of bone and soft tissue to fill defect by moving a disk of bone and formation of new tissue behind it until it docks the host bone [55]. Bifocal distraction osteogenesis, or bone transportation, is a modification of monofocal distraction that involves moving a free segment of living bone to fill an intercalary bone defect [57].

Transport distraction osteogenesis has been used for the treatment of patients with maxillectomy, mandibulectomy [58] due to neoplasms, mandibular symphysial defects, alveolar defects and TMJ ankylosis [59].

\section{Distraction osteogenesis in orthodontics}

It has now been established that a combination of orthodontics with distraction osteogenesis yields good results. The dentoalveolar distraction technique is an innovative method that reduces overall orthodontic treatment time by nearly $50 \%$, with no unfavorable effects on surrounding structures [60]. Studies demonstrated that a skeletal Class I apical base relationship, good facial profile, and optimum intercuspation of the teeth were achieved with the treatment. It was found that an orthodontic treatment combined with mandibular distraction osteogenesis in a patient with mandibular retrusion in the late growth period to be effective for improving stomatognathic function [61]. Distraction osteogenesis provided an efficient surgical alternative to orthognathic surgery for widening the mandible and treatment of transverse mandibular deficiency without extraction of teeth [62].

\section{Alveolar ridge augmentation}

Sufficient amount of alveolar bone is the prerequisite for the prosthetic rehabilitation of a patient with lost or missing teeth. Resorption of bone is unavoidable when it comes to alveolar ridges, be it due to improper functional loading, trauma, or just simply a matter of time. The options available are onlay bone grafting, interpositional bone grafting, guided bone regeneration. Alveolar distraction osteogenesis (ADO) has evolved as a promising procedure for alveolar ridge augmentation prior to implant placement. Distraction osteogenesis provides an opportunity to obtain a natural formation of bone between the distracted segments. Im et al., successfully treted the ankylosed maxillary central incisor by Miniscrewanchored alveolar distraction [63].

\section{Alveolar distraction devices}

- Extraosseous alveolar distractors are placed on the lateral side of the alveolar bone and attached to the transport and host bone segments eg., TRACK. 
- Endosseous device, the distraction rod is inserted into the transport and host bone segments. Some, such as the LEAD System.

- Distractor and oral implant combination device is a prosthetically restorable distractor. Conceptually this approach is superior because the secondary surgeries for distractor removal and implant placement are eliminated.

\section{Regeneration of periodontium - an emerging field} Since distraction osteogenesis emerged as a promising technique of bone regeneration, scientists were hopeful that the same principles could be applied for the regeneration of lost periodontium. They hypothised that periodontium can be consistently distracted towards the tooth crown to promote periodontal bone regeneration. Although only a few attempts have been made, the results obtained were sufficient to establish periodontal bone regeneration as a new treatment alternative for periodontal defects $[64,65]$.

Bavitz et al., created a supraalveolar periodontal defect on the buccal surface of three mandibular teeth of four beagle dogs. The lingual attachment was not compromised. During the same surgical visit, 7 self-tapping $1.5-\mathrm{mm}$ diameter titanium screws were placed inferior to the tooth apices to a depth of approximately 2 to $3 \mathrm{~mm}$. The mucoperiosteal flap was then apically repositioned with the screw heads piercing through the gingival.

After three months corticotomy was performed of 1 to $2 \mathrm{~mm}$ depth. Two orthodontic elastics were then applied from the brackets on the area to the screws in a rectangular pattern measuring approximately $2 \mathrm{~cm} \times 1 \mathrm{~cm}$. The premise was to allow the buccal plate, periodontal ligament, and gingival to slide or distract up the root surfaces, thus regenerating attachment.

The results showed a significant new cementum formation but failed to show new bone deposition.

Faber et al., 2005 attempted the same experiment but ensured the blood supply to the split periodontium through the periosteum. After the surgical production of the periodontal defects in maxillary canines of five mongrel dogs, periodontal distraction was performed.

Results showed that periodontal bone regeneration occurred in all animals. New cellular cementum and periodontal ligament tissue were found in association with the regenerated alveolar bone [65].

\section{Periosteal expansion osteogenesis}

Taking distraction osteogenesis to a step further, recently periosteal expansion osteogenesis has been attempted. The technique is based on the concept that tension in the periosteum can lead to the production of subperiosteal bone without corticotomy or local harvesting of the bone. Highly purified Beta-tricalcium phosphate is biocompatible, biodegradable \& osteoconductive. It gradually degraded during the bone remodelling process and is replaced by mature new bone [66].
Surgical procedure involves the reflection of the mucoperiosteal flap and placement of the beta tricalcium phosphate block lateral to the bone with two titanium screws placed at the inferior border to prevent its inferior displacement and two more screws inserted from the lingual side to push the block labially. After a latency period of 8 days, during which primary wound healing occurred, the lingual screws were advanced by; $0.5 \mathrm{~mm} /$ day for 8 days.

The alveolar form at the experimental region was changed dramatically following lateral expansion with the $\beta$-TCP block. Newly formed bone was observed in the gap between the bone and the $\beta$-TCP block, as well as on the lateral surface of the block. Moreover, the replacement of large parts of $\beta$-TCP with newly formed bone was observed in the $\beta$-TCP block area. However, newly formed bone was not observed over the upper parts of the block.

The study showed the feasibility of periosteal expansion distraction osteogenesis and the potential use of $\beta$-TCP for induction of osteoblastic response in periosteum.

\section{Advantages, disadvantages \& complications of distraction osteogenesis \\ Advantages}

1. Decreased operating time and hospital stay.

2. Can be applied at a younger patient.

3 . It is a relatively simple technique.

4. Does not require blood transfusion and bone grating.

5. The technique is allows simultaneous expansion of associated soft tissue.

6. Distraction osteogenesis permits larger movements and offers greater post operative stability.

\section{Disadvantages}

1. Requirement of second surgical intervention for the removal of distraction device.

2. Pain during distraction phase.

3.Does not correct underlying growth disturbance.

\section{Competing interests}

The authors declare that they have no competing interests.

\section{Publication history}

EIC: Scott Argraves, Medical University of South Carolina, USA.

Received: 20-Mar-2013 Revised: 27-Apr-2013

Re-Revised: 28-Jul-2013 Accepted: 30-Jul-2013

Published: 13-Aug-2013

\section{References}

1. Hadjidakis DJ and Androulakis, II. Bone remodeling. Ann N Y Acad Sci. 2006; 1092:385-96. | Article | PubMed

2. Sant $S$ and Jagtap $A$. Alveolar distraction osteogenesis: revive and restore the native bone. J Prosthodont. 2009; 18:694-7. | Article | PubMed

3. Cohen SR, Rutrick RE and Burstein FD. Distraction osteogenesis of the human craniofacial skeleton: initial experience with new distraction system. J Craniofac Surg. 1995; 6:368-74. I PubMed

4. Costantino PD and Friedman CD. Distraction osteogenesis. 
Applications for mandibular regrowth. Otolaryngol Clin North Am. 1991; 24:1433-43. | PubMed

5. Codvilla A. On the means of lengthening in the lower limb the muscles and tissues which are shortened through deformity. Am J Orthop Surg. 1904; 2:353- 369.

6. Ilizarov $S$ and Rozbruch S. R. Limb Lengthening and Reconstruction Surgery. New York: Informa Healthcare USA Inc. 2007.

7. Snyder CC, Levine GA, Swanson HM and Browne EZ, Jr. Mandibular lengthening by gradual distraction. Preliminary report. Plast Reconstr Surg. 1973; 51:506-8. | PubMed

8. Michieli $S$ and Miotti $B$. Lengthening of mandibular body by gradual surgical-orthodontic distraction. J Oral Surg. 1977; 35:187-92. | PubMed

9. McCarthy JG, Schreiber J, Karp N, Thorne CH and Grayson BH. Lengthening the human mandible by gradual distraction. Plast Reconstr Surg. 1992; 89:1-8; discussion 9-10. | Article | PubMed

10. Guerrero C: Rapid mandibular expansion. Rev Venez Ortod. 1990; 48:1-2.

11. llizarov GA. The tension-stress effect on the genesis and growth of tissues: Part II. The influence of the rate and frequency of distraction. Clin Orthop Relat Res. 1989; 263-85. | Article | PubMed

12. Aronson J, Good B, Stewart C, Harrison B and Harp J. Preliminary studies of mineralization during distraction osteogenesis. Clin Orthop Relat Res. 1990; 43-9. | Article | PubMed

13. Sato M, Ochi T, Nakase T, Hirota S, Kitamura Y, Nomura S and Yasui N. Mechanical tension-stress induces expression of bone morphogenetic protein (BMP)-2 and BMP-4, but not BMP-6, BMP-7, and GDF-5 mRNA, during distraction osteogenesis. J Bone Miner Res. 1999; 14:1084-95. | Article | PubMed

14. Yasui $\mathrm{N}$, Kojimoto $\mathrm{H}$, Shimizu $\mathrm{H}$, Shimomura Y. The effect of osteodistraction on bone, muscle and periosteum. Orthop Clin North Am. 1991; 22: 563-567.

15. Li G, Berven S, Simpson H and Triffitt JT. Expression of BMP-4 mRNA during distraction osteogenesis in rabbits. Acta Orthop Scand. 1998; 69:420-5. | PubMed

16. Liu Z, Luyten FP, Lammens J and Dequeker J. Molecular signaling in bone fracture healing and distraction osteogenesis. Histol Histopathol. 1999; 14:587-95. I PubMed

17. Mizuta H, Nakamura E, Kudo S, Maeda T and Takagi K. Greater frequency of distraction accelerates bone formation in open-wedge proximal tibial osteotomy with hemicallotasis. Acta Orthop Scand. 2004; 75:588-93. | Article | PubMed

18. Xie LK, Wangrangsimakul K, Suttapreyasri S, Cheung LK and Nuntanaranont T. A preliminary study of the effect of low intensity pulsed ultrasound on new bone formation during mandibular distraction osteogenesis in rabbits. Int J Oral Maxillofac Surg. 2011; 40:730-6. | Article | PubMed

19. Hagiwara T and Bell WH. Effect of electrical stimulation on mandibular distraction osteogenesis. J Craniomaxillofac Surg. 2000; 28:12-9. | Article | PubMed

20. Eguchi Y, Wakitani S, Naka Y, Nakamura H and Takaoka K. An injectable composite material containing bone morphogenetic protein-2 shortens the period of distraction osteogenesis in vivo. $J$ Orthop Res. 2011; 29:452-6. | Article | PubMed

21. Park BH, Yoon SJ, Jang KY, Kim MR, Lee HS, Kim KB, Park H, Lee SY, Park HS, Lim ST, Song KJ and Kim JR. COMP-angiopoietin-1 accelerates bone formation during distraction osteogenesis. Bone. 2010; 46:1442-8. | Article | PubMed

22. Yao Y, Wang G, Wang Z, Wang C, Zhang H and Liu C. Synergistic enhancement of new bone formation by recombinant human bone morphogenetic protein-2 and osteoprotegerin in trans-sutural distraction osteogenesis: a pilot study in dogs. J Oral Maxillofac Surg. 2011; 69:e446-55. | Article | PubMed

23. Latalski M, Elbatrawy YA, Thabet AM, Gregosiewicz A, Raganowicz $T$ and Fatyga $M$. Enhancing bone healing during distraction osteogenesis with platelet-rich plasma. Injury. 2011; 42:821-4. | Article | PubMed
24. Ma D, Ren L, Yao H, Tian W, Chen F, Zhang J, Liu Y and Mao T. Locally injection of cell sheet fragments enhances new bone formation in mandibular distraction osteogenesis: a rabbit model. J Orthop Res. 2013; 31:1082-8. | Article | PubMed

25. Pedersen TO, Xing Z, Finne-Wistrand A, Hellem S and Mustafa K. Hyperbaric oxygen stimulates vascularization and bone formation in rat calvarial defects. Int J Oral Maxillofac Surg. 2013; 42:907-14. I Article I PubMed

26. Ali MN, Kobayashi T, Tanaka M, Ohshima H, Ejiri S and Saito C. Effects of intermittent parathyroid hormone treatment on new bone formation during distraction osteogenesis in the rat mandible. Oral Surg Oral Med Oral Pathol Oral Radiol. 2012; 114:e36-42. | Article | PubMed

27. Samchukov ML, Cherkashin AM, Cope JB. Distraction osteogenesis: origins and evolution. In: McNamara JA Jr, Trotman CA, eds. Advances in Craniofacial Orthopedics. Volume 34. Craniofacial Growth Series. Ann Arbor: Center for Human Growth and Development, University of Michigan; 1998:1-35.

28. Molina F and Ortiz Monasterio F. Mandibular elongation and remodeling by distraction: a farewell to major osteotomies. Plast Reconstr Surg. 1995; 96:825-40; discussion 841-2. | Article | PubMed

29. Cope JB, Samchukov ML and Cherkashin AM. Mandibular distraction osteogenesis: a historic perspective and future directions. Am J Orthod Dentofacial Orthop. 1999; 115:448-60. | Article | PubMed

30. Razdolsky Y, Pensler JM, Dessner S. Skeletal distraction for mandibular lengthening with a completely intraoral toothborn distractor. In: McNamara JA Jr, Trotman CA, eds. Advances in craniofacial orthopedics. Volume 34. Craniofacial Growth Series. Ann Arbor: Center for Human Growth and Development, University of Michigan; 1998:117-40.

31. Burstein FD and Williams JK. Mandibular distraction osteogenesis in Pierre Robin sequence: application of a new internal single-stage resorbable device. Plast Reconstr Surg. 2005; 115:61-7; discussion 68-9. | Article | PubMed

32. Fritz MA and Sidman JD. Distraction osteogenesis of the mandible. Curr Opin Otolaryngol Head Neck Surg. 2004; 12:513-8. | Article | PubMed

33. Kuriakose MA, Shnayder Y and DeLacure MD. Reconstruction of segmental mandibular defects by distraction osteogenesis for mandibular reconstruction. Head Neck. 2003; 25:816-24. | Article | PubMed

34. Miloro M. Mandibular distraction osteogenesis for pediatric airway management. J Oral Maxillofac Surg. 2010; 68:1512-23. | Article | PubMed

35. Mudd PA, Perkins JN, Harwood JE, Valdez S and Allen GC. Early intervention: distraction osteogenesis of the mandible for severe airway obstruction. Otolaryngol Head Neck Surg. 2012; 146:467-72. | Article | PubMed

36. Rachmiel A, Potparic Z, Jackson IT, Sugihara T, Clayman L, Topf JS and Forte RA. Midface advancement by gradual distraction. BrJ Plast Surg. 1993; 46:201-7. | Article | PubMed

37. Polley JW, Figueroa AA, Charbel FT, Berkowitz R, Reisberg D and Cohen M. Monobloc craniomaxillofacial distraction osteogenesis in a newborn with severe craniofacial synostosis: a preliminary report. J Craniofac Surg. 1995; 6:421-3. | PubMed

38. Nakajima H, Sakamoto Y, Tamada I, Ogata H, Kishi K and Sakamoto T. Maxillary-driven simultaneous maxillo-mandibular distraction for hemifacial microsomia. J Craniomaxillofac Surg. 2011; 39:549-53. | Article | PubMed

39. Molina F. Combined maxillary and mandibular distraction osteogenesis. Semin Orthod. 1999; 5:41-5. | PubMed

40. Lee DW, Ham KW, Kwon SM, Lew DH and Cho EJ. Dual midfacial distraction osteogenesis for Crouzon syndrome: long-term follow-up study for relapse and growth. J Oral Maxillofac Surg. 2012; 70:e24251. | Article | PubMed

41. Satoh $\mathrm{K}$, Mitsukawa $\mathrm{N}$ and Hosaka Y. Dual midfacial distraction osteogenesis: Le Fort III minus I and Le Fort I for syndromic 
craniosynostosis. Plast Reconstr Surg. 2003; 111:1019-28. | Article | PubMed

42. Iannetti G, Ramieri V, Pagnoni M, Fadda MT and Cascone P. Le Fort III external midface distraction: surgical outcomes and skeletal stability. J Craniofac Surg. 2012; 23:896-900. | Article | PubMed

43. Takano M, Kasahara K, Ogawa C, Katada $\mathrm{H}$ and Sueishi K. A case of Sotos syndrome treated with distraction osteogenesis in maxilla and mandible. Bull Tokyo Dent Coll. 2012; 53:75-82. | Article | PubMed

44. Mitsukawa N, Satoh K, Morishita T and Hosaka Y. Clinical application of distraction osteogenesis for traumatic maxillofacial deformities. $J$ Craniofac Surg. 2006; 17:431-7. | Article | PubMed

45. Liu Y, Chen J, Yan F and Ping F. Mandible reconstruction with transport-disc distraction osteogenesis in children of deciduous dentition. Int J Oral Maxillofac Surg. 2012; 41:1223-8. | Article | PubMed

46. Scolozzi P. Distraction osteogenesis in the management of severe maxillary hypoplasia in cleft lip and palate patients. J Craniofac Surg. 2008; 19:1199-214. | Article | PubMed

47. Hegab AF. Closure of the alveolar cleft by bone segment transport using an intraoral tooth-borne custom-made distraction device. $J$ Oral Maxillofac Surg. 2012; 70:e337-48. | Article | PubMed

48. Rachmiel A, Even-Almos M and Aizenbud D. Treatment of maxillary cleft palate: Distraction osteogenesis vs. orthognathic surgery. Ann Maxillofac Surg. 2012; 2:127-30. | Article | PubMed Abstract | PubMed Full Text

49. Pinto LP, Bell WH, Chu S and Buschang PH. Simultaneous 3-dimensional Le Fort I/distraction osteogenesis technique: positional changes. J Oral Maxillofac Surg. 2009; 67:32-9. | Article | PubMed

50. Sugawara $\mathrm{Y}, \mathrm{Uda} \mathrm{H}$, Sarukawa $\mathrm{S}$ and Sunaga A. Multidirectional cranial distraction osteogenesis for the treatment of craniosynostosis. Plast Reconstr Surg. 2010; 126:1691-8. | Article | PubMed

51. Phillips JH, Forrest CR and Gruss JS. Current concepts in the use of bone grafts in facial fractures. Basic science considerations. Clin Plast Surg. 1992; 19:41-58. | Article | PubMed

52. Capote-Moreno AL, Naval-Gias L, Munoz-Guerra MF and RodriguezCampo FJ. Zygomatic distraction osteogenesis for correction of midfacial support after hemimaxillectomy: experience and technical considerations. J Oral Maxillofac Surg. 2013; 71:e189-97. | Article | PubMed

53. McCormick SU, McCarthy JG, Grayson BH, Staffenberg D and McCormick SA. Effect of mandibular distraction on the temporomandibular joint: Part 1, Canine study. J Craniofac Surg. 1995; 6:358-63. | Article | PubMed

54. McCormick SU, Grayson BH, McCarthy JG and Staffenberg D. Effect of mandibular distraction on the temporomandibular joint: Part 2, Clinical study. J Craniofac Surg. 1995; 6:364-7. | Article | PubMed

55. Schwartz HC and Relle RJ. Distraction osteogenesis for temporomandibular joint reconstruction. J Oral Maxillofac Surg. 2008; 66:718-23. | Article | PubMed

56. Yu H, Shen G, Zhang S and Wang X. Gap arthroplasty combined with distraction osteogenesis in the treatment of unilateral ankylosis of the temporomandibular joint and micrognathia. Br J Oral Maxillofac Surg. 2009; 47:200-4. | Article | PubMed

57. Bouletreau PJ, Warren SM, Paccione MF, Spector JA, McCarthy JG and Longaker MT. Transport distraction osteogenesis: a new method to heal adult calvarial defects. Plast Reconstr Surg. 2002; 109:1074-84. | Article | PubMed

58. Cai M, Lu X, Shen G, Wang X and Cheng AH. Customized bifocal and trifocal transport distraction osteogenesis device for extensive mandibular reconstruction. J Craniofac Surg. 2011; 22:562-5. I Article | PubMed

59. Mehrotra D. Reconstruction of ramus-condyle unit with transport distraction osteogenesis: Report of eight cases and review of literature. J Oral Biol Craniofac Res. 2012; 2:144-148. | Article

60. Iseri $\mathrm{H}$, Kisnisci $\mathrm{R}, \mathrm{Bzizi} \mathrm{N}$ and Tuz $\mathrm{H}$. Rapid canine retraction and orthodontic treatment with dentoalveolar distraction osteogenesis.
Am J Orthod Dentofacial Orthop. 2005; 127:533-41. | Article | PubMed

61. Maeda A, Soejima K, Ogura M, Ohmure H, Sugihara K and Miyawak $S$. Orthodontic treatment combined with mandibular distraction osteogenesis and changes in stomatognathic function. Angle Orthod. 2008; 78:1125-32. | Article | PubMed

62. Guerrero CA, Bell WH, Contasti GI and Rodriguez AM. Mandibular widening by intraoral distraction osteogenesis. $\mathrm{Br} J$ Oral Maxillofac Surg. 1997; 35:383-92. | Article | PubMed

63. Im JJ, Kye MK, Hwang KG and Park CJ. Miniscrew-anchored alveolar distraction for the treatment of the ankylosed maxillary central incisor. Dent Traumatol. 2010; 26:285-8. | Article | PubMed

64. Bavitz JB, Payne JB, Dunning D, Glenn A and Koka R. The use of distraction osteogenesis to induce new suprabony periodontal attachment in the beagle dog. Int J Periodontics Restorative Dent. 2000; 20:596-603. I PubMed

65. Faber J, Azevedo RB and Bao SN. Distraction osteogenesis may promote periodontal bone regeneration. J Dent Res. 2005; 84:75761. | Article | PubMed

66. Yamauchi K, Takahashi T, Funaki K and Yamashita Y. Periosteal expansion osteogenesis using highly purified beta-tricalcium phosphate blocks: a pilot study in dogs. J Periodontol. 2008; 79:9991005. | Article | PubMed

67. McAllister BS and Gaffaney TE. Distraction osteogenesis for vertical bone augmentation prior to oral implant reconstruction. Periodontol 2000. 2003; 33:54-66. | Article | PubMed

\section{Citation:}

Mahajan A, Kashyap D, Singh B, Kumar A and Poonam. Scope of distraction osteogenesis in dentisrty a mini review. J Regen Med Tissue Eng. 2013; 2:3. http://dx.doi.org/10.7243/2050-1218-2-3 